\title{
Polymorphism of the CYP2C9 and VKORC1 genes: a comment
}

\author{
Rujittika Mungmunpuntipantip ${ }^{1}$ (D), Viroj Wiwanitkit ${ }^{2}$
}

How to cite: Mungmunpuntipantip R, Wiwanitkit V. Polymorphism of the CYP2C9 and VKORC1 genes: a comment. J Vasc Bras. 2021;20:e20210108. https://doi.org/10.1590/1677-5449.210108

Dear editor,

We would like to share ideas on "Polymorphism of the CYP2C9 and VKORC1 genes in patients on the public health system of a municipality in Southern Brazil.. " Tozato et al. studied polymorphisms of the CYP2C9 and VKORC1 genes, warfarin, and Time in Therapeutic Range (TTR) and concluded that "An association was observed between the polymorphisms and the warfarin doses taken by the patients. However, there was no association with adverse events or the time spent within the therapeutic range in this sample." The study drew conclusions that were not supported by its findings. It should only have concluded on the genetic epidemiology of polymorphisms. There are many confounding factors. An important consideration is the effect of other polymorphisms that are not assessed in the present study. Examples of these polymorphisms are CYP4F2 V433M, ABCB1, PROC, EPHX1, and SETD1A. ${ }^{2,3}$

\section{REFERENCES}

1. Colet $\mathrm{C}$, Botton MR, Schwambach $\mathrm{KH}$, Amador TA, Heineck I. Polymorphism of the CYP2C9 and VKORC1 genes in patients on the public health system of a municipality in Southern Brazil. J Vasc Bras. 2021;20:e20200214. http://dx.doi.org/10.1590/16775449.200214. PMid:34104133.

2. Naushad SM, Kutala VK, Hussain T, Alrokayan SA. Pharmacogenetic determinants of warfarin in the Indian population. Pharmacol Rep. 2021. Epub ahead of print. PMid:34106453.

3. Xu Q, Zhang S, Wu C, et al. Genetic associations with stable warfarin dose requirements in $\mathrm{Han}$ Chinese patients. J Cardiovasc
Pharmacol. 2021;78(1):e105-11. http://dx.doi.org/10.1097/ FJC.0000000000001048. PMid:33958549.

Correspondence Rujittika Mungmunpuntipantip Private Academic Consultant Bangkok, Thailand Tel.: 662256555676 E-mail: rujittika@gmail.com

Author information RM - Private Academic Consultant. VW - Honorary professor; Dr DY Patil University. 


\section{RESPONSE LETTER}

\section{Dear Editor,}

We agree with the point made in this Letter to the Editor. As we mentioned in our article, some associations that have been identified in earlier publications were not detected in our study and we believe that this may be because the population analyzed in our study was insufficient for certain causal inferences. We also agree that the clinical response is the result of the activity of multiple genes, as stated in the Letter, but it was not possible to include all of these genes for financial reasons, so we chose those that have the greatest influence on warfarin efficacy according to the literature.

Christiane de Fátima Colet (D)

Correspondence
Christiane de Fátima Colet
Universidade Regional do Noroeste do Estado do Rio Grande do
Sul - Unijuí
Rua do Comércio, 3000 - Bairro Universitário
CEP 98700-000 - ljú (RS), Brasil
Tel.: +55 (55) 3332-0461
E-mail: christiane.colet@unijui.edu.br
Author information
CFC - PhD in Ciências Farmacêuticas; Adjunct Professor,
Departamento de Ciências da Vida, Universidade Regional do
Noroeste do Estado do Rio Grande do Sul (UNIJUÍ).

